\title{
Interwoven connections: The Stoddard-Templeton design studio and design library 1843-2005
}

\author{
Helena Britt and Duncan Chappell
}

\begin{abstract}
7 he historical importance of carpet design and manufacture to the West of
1 Scotland is now largely forgotten, eclipsed by heavy industries such as
\end{abstract} shipbuilding for which Glasgow is justly famous. Yet, in their heyday, carpet manufacturers A. F. Stoddard of Elderslie, Renfrewshire and James Templeton of Glasgow Green provided employment for thousands of workers. Indeed, by the 1950s Templeton was Glasgow's largest single employer. For decades the companies supplied carpets to the world's ocean liners, heads of state, royalty, corporations and state institutions, yet in 2005 the combined companies filed for bankruptcy. This paper describes efforts to save and interpret the historical collections, principally concentrating on the design library now held at the Glasgow School of Art. It follows a recent research project, exhibition and publication that explored the development of the Library and its use within the design process.

\section{The History of Stoddard-Templeton}

In 1839 James Templeton, a shawl manufacturer from Glasgow, patented the Chenille Axminster production process. Realizing that the technique could be applied to carpets, he was soon pioneering the mechanization of carpet manufacture, forming James Templeton \& Co in 1843. In the succeeding decades the company became world-renowned for the quality of its carpets and designs. It supplied carpets for the coronations of George V and VI and Elizabeth II at Westminster Abbey, as well as for the House of Commons, the White House, the parliaments of Australia, South Africa and New Zealand, the Titanic and Queen Mary liners, and the Royal Reception Room at the 1851 Great Exhibition. By 1892 an ornate landmark factory, modelled on the Doge's Palace in Venice, was completed on Glasgow Green by architect William Leiper.

Meanwhile, the American abolitionist Alfred Francis Stoddard had begun producing carpets and textiles upon acquiring a bankrupt Paisley shawl mill in 1862. A. F. Stoddard \& Co designed carpets for the marriage of Princess Elizabeth and Prince Philip, and for Liberty of London. Both companies also produced ranges for the domestic market, exporting to the four corners of the Empire. It is perhaps particularly appropriate to rediscover their work in this year, when the Commonwealth of Nations will visit Glasgow for the XX Commonwealth Games.

In addition to their in-house design teams, the companies employed an array of designers of repute, including Charles Voysey, Walter Crane, Frank Brangwyn, Enid Marx, Marion Dorn and Mary Quant. ${ }^{1}$ Over the years both companies expanded and acquired a number of subsidiary companies such as Ronald Jack \& Co of Paisley, Gray's of Ayr, Henry Widnell \& Stewart of Bonnyrigg, and Blackwood Morton \& Sons of Kilmarnock. During the 1980s Stoddards acquired Templetons and the companies merged to form Stoddard International. Sadly in the early 20th century the demise of these illustrious companies became inescapable. The fashion for wooden floors, and competition from cheaper 
manufacturers overseas proved too much. In January 2005 Stoddard International filed for bankruptcy. With the closure, West of Scotland carpet design and manufacture become an industry that was at risk of being erased from our collective memory.

\section{The Stoddard-Templeton collections and design library}

Yet, within the bones of the company some precious DNA remained: unique archives, books, prints, folios, and textiles that could help tell the story of this important industry and its people. Realizing the potential loss of these collections, Glasgow School of Art, University of Glasgow Archives and Glasgow Museums formed a consortium to purchase and safeguard them for the public and future researchers alike. Together, the three partners possessed a wealth of experience in acquiring, managing, preserving and providing access to historical collections. Working collaboratively with the receivers, and following a project planning grant from the Heritage Lottery Fund, we were able to put together a plan that would see the collections managed, catalogued and preserved for the future. Although negotiations and funding applications ultimately took four years, finally in 2009 we were able to complete purchase, thanks to funding from the National Heritage Memorial Fund, National Fund for Acquisitions and Friends of National Libraries. Today the collections of StoddardTempleton are distributed across the project partners. The historical carpets rest with Glasgow Museums, the business records and design archives with University of Glasgow Archives, and the design library, along with a small number of carpet samples, with the Glasgow School of Art.

Given the historical links between GSA and Templetons, it is particularly apt that the library should finally reside with us. In the 19th century, Templetons were annual contributors to many of the School's prize funds and scholarships. ${ }^{2}$ The company contributed $£ 250$ to the fund to build the renowned Charles Rennie Mackintosh building, completed in two stages between 1896-1909. From 1875 John Stuart Templeton sat on the School's Committee of Management. Stoddard-Templeton designers attended classes, students undertook work placements, and graduates gained employment in the design studio. Templetons even gifted a tuft loom to the School for use by our students, and to this day a bursary in the name of Bill Naysmith, Stoddard's design director from the 1990s, is awarded to our students for textile excellence.
The design library was carefully developed over a century by both Templetons and Stoddards to support and inspire design thinking and skills. To provide insight into design trends from around the world, company directors would purchase library items when travelling; a portfolio published in Paris $^{3}$ contains the inscription 'bought by Mr J. Glass, 1911'. A book published in Sydney and signed by the author coincides with a 1959 trip to Australia by Robert Anderson, Templeton's then assistant chief designer.

The library was often the starting point in the design process, providing initial ideas or jumping-off points for commissioned designs. The quality and rarity of many of the volumes indicate that expense was seldom spared when ensuring the designers had access to the contemporary, often continental, designs of the day. The library is a rich source of material for textiles, ornament, colour studies, flat pattern, decoration and modernism. A good proportion of the material, especially from the 1880s to the 1930s, was acquired from abroad: the USA, France, Spain, Italy, Austria, Germany, Czechoslovakia, Poland, Sweden, Finland, China, Japan and India. The work of modernist designers such as Seguy, Garcelon, Benedictus, Charlet, Darcy, Sorokine, Gladky and Sonia Delaunay is extensively represented, much of it with richly vibrant, hand-coloured pochoirs. Several of these volumes are now extremely rare, and sometimes unique.

The design library today is a little smaller than would have been the case when it was in situ in the factories. Space constraints meant that we had to be judicious in what we could take, and many volumes were of no historical interest, representing simple cheap paperbacks on specific artists. A careful appraisal of the library was made, from which we selected the most important and historically relevant volumes. When the volumes first arrived with us, they were unordered, uncatalogued and in a poor state of repair. Most of the volumes are loose-leaf design folios, and over the years hundreds of plates had become separated from their host folios. Our team of enthusiastic and dedicated volunteers set about sorting through this material, and over the course of the next two years they were able to reconstruct the library as it once would have been.

To provide public access to the holdings we catalogued each volume to accepted international standards. We were originally recommended to subsume the volumes into our existing collections, but once they arrived with us we decided, on the contrary, to retain them as a discrete collection under their inhouse classification system. The Library was carefully arranged to aid the design process, with folios organized by theme or style, such as 'floral', 'art deco', 


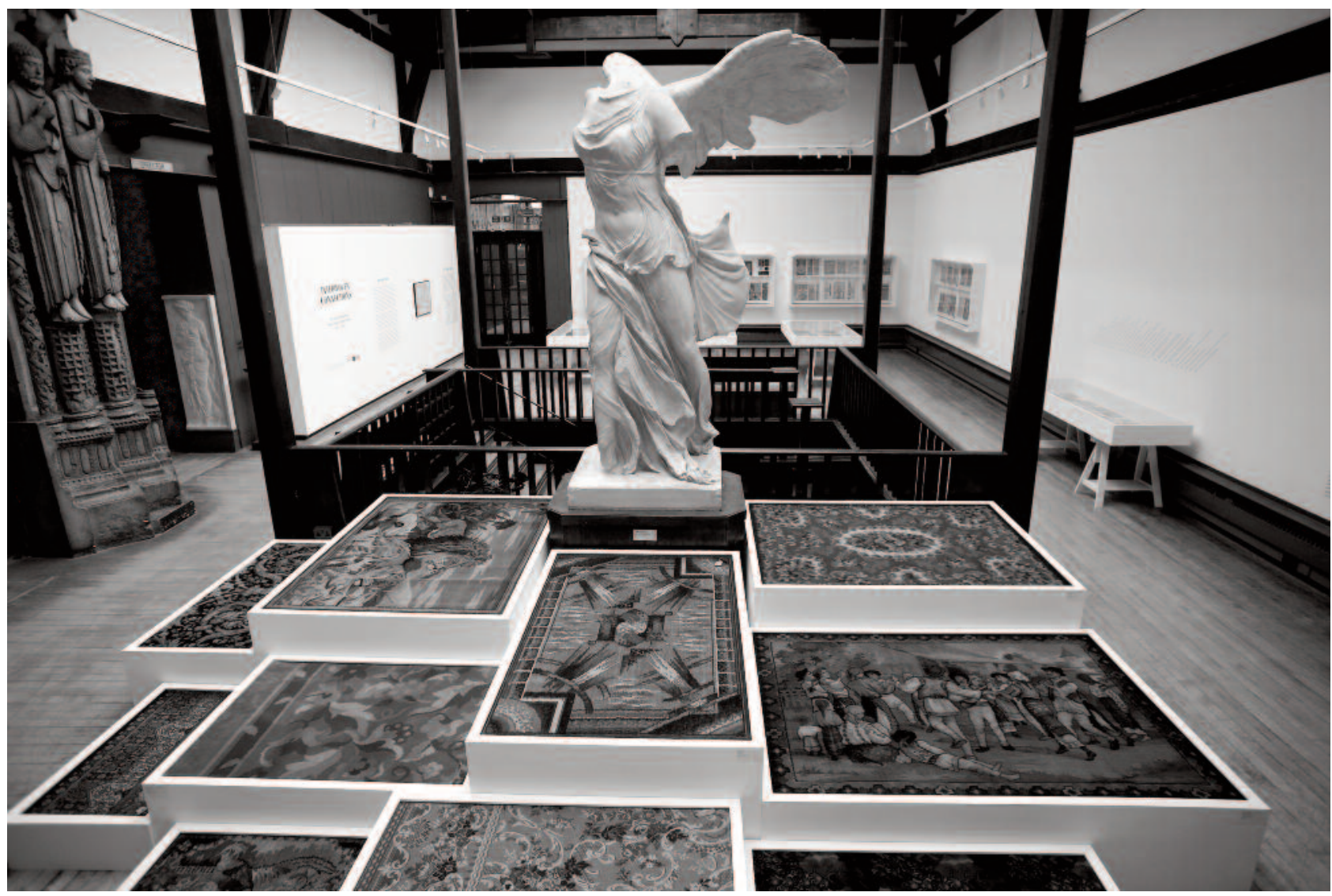

Fig. 1 Photograph of exhibition Interwoven connections: the Stoddard Templeton design studio and design library, 1843-2005 held at Mackintosh Museum, Glasgow School of Art, $8^{\text {th }}$ November 2013 - $11^{\text {th }}$ January 2014. Photo courtesy of Glasgow School of Art Exhibitions.

or 'Japanese'. It was an arrangement designed for browsing, and reflects the way that our own design students continue to use their modern library to this day. Today, the design library can be accessed by anyone with a genuine research interest. It forms a discrete collection within our wider special collections, and numbers some 670 volumes. Guides and bibliographies to the collection can be found on our website, with the full collection searchable through our online catalogue. ${ }^{5}$ As we discover new information about the volumes we are continuing to expand these records. Due to their historical value, the volumes reside in closed access, and are fetched for interested researchers upon request. For this reason, access is by prior appointment only.

\section{The Interwoven Connections Research Project}

The year-long project Interwoven connections: the Stoddard Templeton design studio and design library 1843-2005, funded by the Royal Society of Edinburgh, provided an opportunity to study and analyse the design library. Outputs included an exhibition (figure 1), publication ${ }^{6}$, film $^{7}$, public lecture ${ }^{8}$, gallery talks and studio workshops. The objective of the project was to increase knowledge and understanding of carpet design in Scotland, and by extension textile design history, by examining the workings of the Stoddard-Templeton design studio and in particular the utilization of the design library. In addition to time spent examining design library folios, related archival items were consulted at the University of Glasgow Archive Services, Museum of Carpet, Kidderminster and the Clothworkers' Centre for the Study and Conservation of Textiles and Fashion at the Victoria \& Albert Museum. Research material included books, portfolios, brochures, catalogues, company records, photographs, design sketches, notebooks, design papers, textile samples and carpets. Films held by the Scottish Screen Archive, produced by the companies for promotional purposes, proved particularly insightful. Interviews were held with a number of individuals who worked in the Stoddard-Templeton design studios, including former slab boys and girls 9 , apprentices, sketchers, designers, colourists, chief designers, design coordinators, marketing managers and archivists. Many fascinating stories have been captured, with several personal archives uncovered and explored as part of the research process. In certain instances these 
archives have been donated and will be added to the overall collections. The oral history interviews provided fascinating insights into the workings of the design studio, the carpet design process, and design library utilization.

\section{The design library in the design process}

Since its foundation, the copying and reproducing of existing designs has been part of the carpet design process. Many versions of famous Persian carpets such as Ardebil, Chelsea and Trinitarias were produced; a carpet produced by Templetons for a the Glasgow International Exhibition of 1901 featured a

... reproduction on a slightly smaller scale of one of the best known Persian carpets... the famous sixteenth century Ardebil Holy Carpet, which... hangs in the South Kensington Museum. ${ }^{10}$

Although the design library contains many folios of well-known carpets, it is probable that copying would have occurred from the originals with designers often sent to the V\&A to sketch. Exemplar carpets were also purchased so that designers could copy and adapt

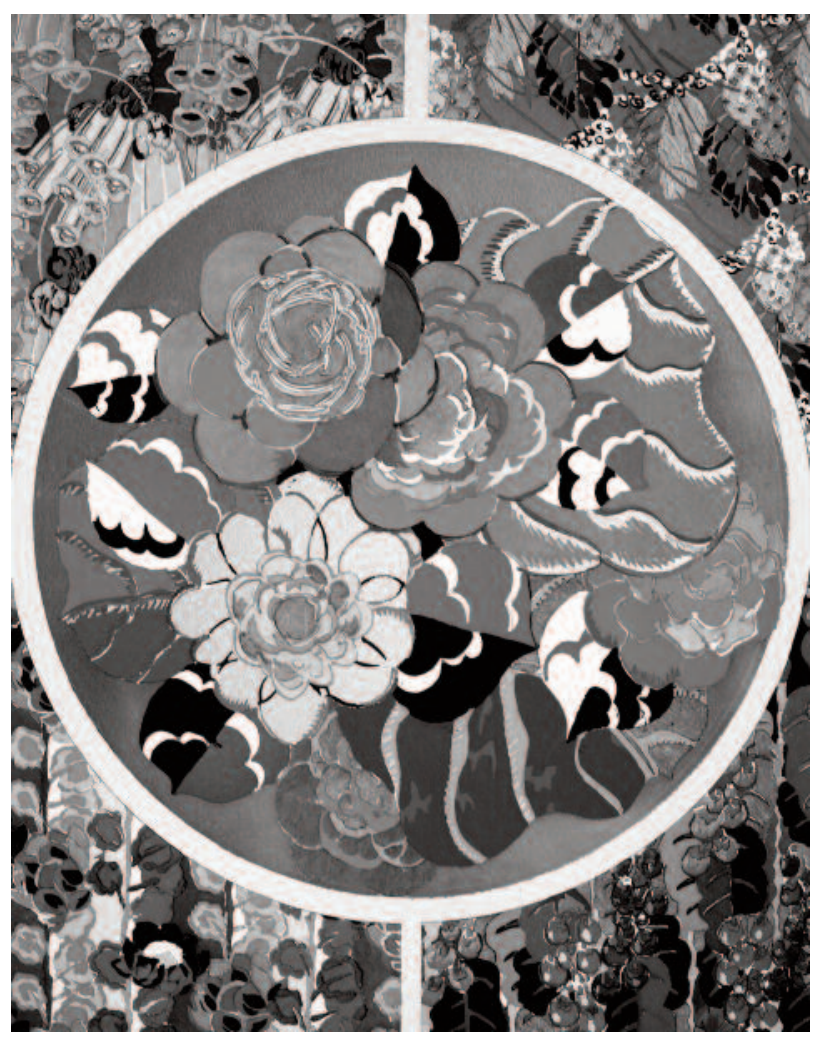

Fig. 2 Detail of plate from Edouard Benedictus, Relais 1930: quinze planches donnant quarante-deux motifs décoratifs (Paris: Vincent, Fréal et Cie, 1931).

Photo courtesy of Glasgow School of Art Library. designs. Templeton's version of the Trinitarias carpet was described as 'undoubtedly one of the finest machine-made carpets produced in this or any other country during the past two decades.'11

From the outset of Interwoven Connections it was hoped that linkages between design library items, design sketches and manufactured carpets would be affirmed. In certain instances it has been possible to identify where specific plates or motifs from portfolios in the design library have been directly copied and manufactured into carpets. A 1924 design by Edouard Benedictus $^{12}$ (figure 2) was enlarged and incorporated into a Sandringham Axminster carpet Tomato plant design (figure 3). A section from the same Benedictus portfolio was used to inspire a carpet by Blackwood Morton \& Sons in the 1980s for the Golden riches Axminster range. ${ }^{13}$ A section of a plate from a portfolio published by Christian Stoll in $1910^{14}$ features in a 1983 Stoddard Commercial carpet catalogue. $^{15}$

Whilst cataloguing the design library we were excited to find small pieces of evidence of how the volumes may have been used by designers during the design process: squares of tracing paper in which motifs from the volumes have been isolated and cribbed; manuscript drawings and doodles on the reverse of many plates; inscriptions linking particular

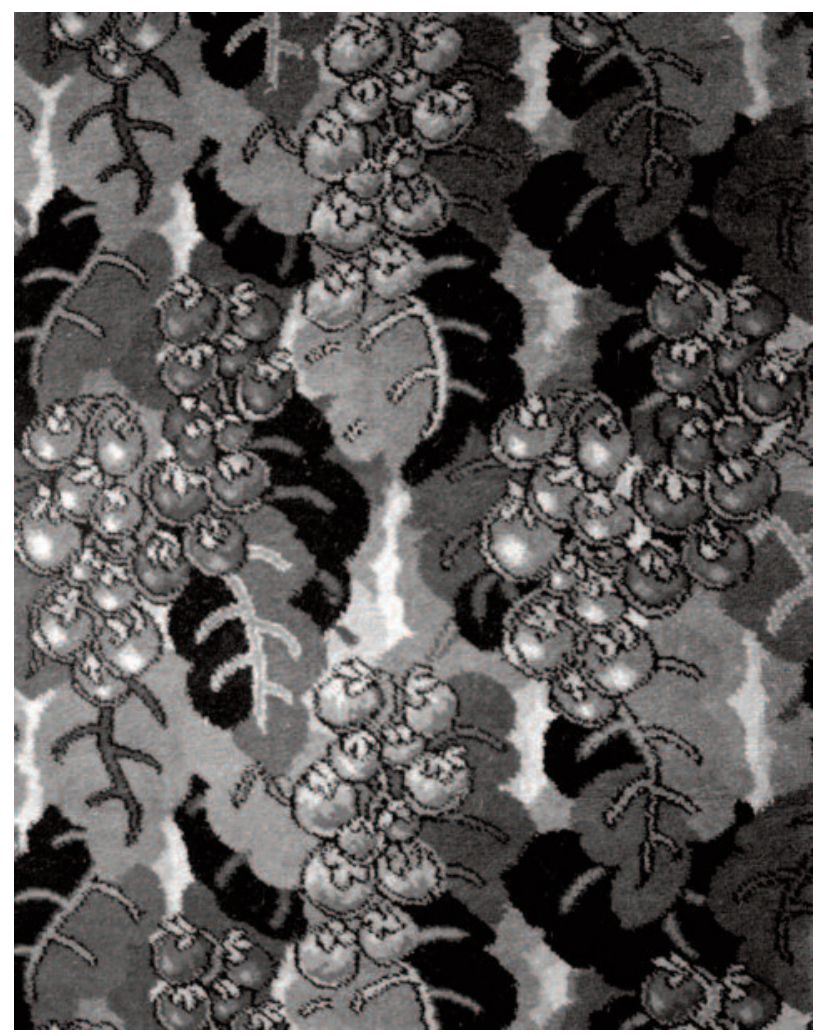

Fig. 3 Photograph of Tomato plant design 1186 (Glasgow, James Templeton \& Co., date unknown). Photo courtesy of Glasgow School of Art Archives \& Collections. 
volumes to specific designers. The addition of gridded pencil lines and tracings to plates signals the replication and possibly enlargement of various motifs. Pencil marks and notes point to the selection of certain elements on the basis of shape and colour.

At Stoddards in the 1950s access to the design library was restricted, with folios kept in the office of the chief designer Walter Bartrum and distributed only when deemed necessary. This changed in the early 1960s when Bartrum's successor, Bill Murray, moved the reference material into the design studio for designers to access whenever they required inspiration. Due to acquisitions and mergers in the early 1980s, the portfolios, books, design sketches and design papers amassed by Stoddard-Templeton and their subsidiary companies came together. A librarian, and then company archivist, organised and collated the collection. The resulting Guide to Stoddard archive and library colour code $e^{16}$, compiled in the 1990s to assist navigation of the collection, is still in current use in the design library. It is evident that by the 1980s the design library was frequently used within the design studio and even featured in promotional items. A catalogue from the period ${ }^{17}$ shows a designer surrounded by design library items. The Stoddard Mercia contact design portfolio ${ }^{18}$ contains a selection of designs taken from the archive collections of the Elderslie studio. When Stoddard purchased the textile company Sekers in 1998, the design library and other company archives informed the subsequent design of printed and woven fabrics. However, the extent to which the design library was used varied throughout Stoddard-Templeton history. While some designers fully utilized the Library, others referred to contemporary magazines and influences outside of the studio.

\section{Future Research}

Although Interwoven Connections has now ended, the project has brought to the fore individuals, previously untraceable, who were connected to StoddardTempleton. There is scope for further investigation into specific rare items within the design library, and additional examination of the group of StoddardTempleton carpet samples held by in Glasgow School of Art Archives and Collections. Our future plans for the collection include potential digitisation and virtual exhibition, in order to make its unique content more easily accessible to a wider audience. There is also scope for research projects that take a wider, more holistic look across the three distributed collections, or that seek to capture the hitherto unrecorded memories and knowledge of past Stoddard-
Templeton designers. These propositions hold out the hope that the history of the once prestigious Scottish carpet industry is captured and made available to future generations.

\section{References}

1. A number of examples reside in the Victoria \& Albert Museum. See http://collections.vam.ac.uk/

2. Information taken from annual reports held in Glasgow School of Art Archives and Collections http://www.gsa.ac.uk/about-gsa/library-learningresources/archives-collections-centre/

3. Gobelins Tapestries, Les modeles et le Musée des Gobelins (Paris: Armand Guerinet, 1900).

4. Clive Carney, International interiors and design (Sydney: Angus and Roberts, 1959).

5. See

http://www2.gsa.ac.uk/library/special_collections. $\underline{\mathrm{html}}$ and http://capitadiscovery.co.uk/gsa/

6. Interwoven connections: the Stoddard Templeton design studio and design library, 1843-2005

(Glasgow: Glasgow School of Art). Catalogue of an exhibition curated by Helena Britt at the Mackintosh Museum, Glasgow School of Art, 8 November 2013-11 January 2014.

7. Interwoven connections (Glasgow: Glasgow School of Art). Film of the exhibition. See http://vimeo.com/80325935

8. Helena Britt \& Duncan Chappell, Interwoven connections (Glasgow: Glasgow School of Art). Public lecture given at Glasgow School of Art, 10 January 2014. See http://vimeo.com/84115673

9. John Byrne's 1978 play The slab boys is a semiautobiographical account of his time as a Stoddards 'slab boy', manual workers who would grind pigments for designers on large marble slabs.

10. Fred Young, A century of carpet making (Glasgow: James Templeton \& Co., 1944), 55.

11. James Templeton \& Co., Templeton presents carpets of distinction (Glasgow: University of Glasgow Press, 1951), 16.

12. Edouard Benedictus, Relais 1930: quinze planches donnant quarante-deux motifs décoratifs (Paris: Vincent, Fréal et Cie, 1931).

13. Blackwood Morton and Sons, Golden riches catalogue (Kilmarnock: BMK, 1980). Museum of Carpet, Kidderminster, CS/UK/STD/5. The catalogue incorrectly claims the design is inspired by the work of Seguy.

14. Christian Stoll, Kunstgewerbliche Schmuckformen fur die Flache - Band 1 (Plauen: Christian Stoll, 1910). 
15. Stoddard Carpets, Stoddard commercial carpets contract Axminster booklet (Elderslie: Stoddard Carpets, 1983). Museum of Carpet, Kidderminster, UKTB/STD/2.

16. Guide to Stoddard archive and library colour code. Records of Stoddard International plc, University of Glasgow Archive Services, GB0248 STOD/200/2/15/6/1.

17. Blackwood Morton and Sons, The creative approach brochure (Kilmarnock: BMK, c1980). Museum of Carpet, Kidderminster UKTB/BMK/3.

18. Stoddard Mercia, The Stoddard Mercia contact design portfolio (Elderslie: Stoddard Mercia, c1980). Collection of Stewart Roxburgh.
Helena Britt

Design Researcher

Glasgow School of Art

167 Renfrew Street

Glasgow $G 36 R Q$

UK

Email: h.britt@gsa.ac.uk

Duncan Chappell

Academic Liaison Librarian

Glasgow School of Art

167 Renfrew Street

Glasgow $G 36 R Q$

UK

Email: d.chappell@gsa.ac.uk 